\title{
A Prospective Study of Factors Associated with Risk of Turnover among Care Workers in Group Homes for Elderly Individuals with Dementia
}

\author{
Miwa Suzumura $^{1}$, Yasuhiro Fushiki ${ }^{1}$, Kota Kobayashi ${ }^{2}$, Asae Oura ${ }^{3}$, \\ Shigeo Suzumura ${ }^{4}$, Masafumi Yamashita ${ }^{4}$ and Mitsuru Mori ${ }^{1}$ \\ ${ }^{1}$ Department of Public Health, Sapporo Medical University School of Medicine, Japan, ${ }^{2}$ Mental Assist Hokkaido, \\ Japan, ${ }^{3}$ Department of Public Health, Kochi University School of Medicine, Japan and ${ }^{4}$ Shingu Prefectural Health \\ Center, Japan
}

\begin{abstract}
A Prospective Study of Factors Associated with Risk of Turnover among Care Workers in Group Homes for Elderly Individuals with Dementia: Miwa Suzumura, et al. Department of Public Health, Sapporo Medical University School of MedicineObjectives: A prospective study was conducted to assess factors associated with risk of turnover among care workers in group homes (GHs) for elderly individuals with dementia. Methods: In January, 2010, 51 out of $238 \mathrm{GHs}$ in Sapporo City responded to our request for participation in a survey. During February and March of 2010,438 out of 700 care workers $(62.6 \%)$ in the $\mathrm{GHs}$ returned a completed questionnaire to us. They were followed up with until March of 2012, and 395 subjects $(90.1 \%)$ responded to our survey, which was conducted twice. Over the course of 2 years, 91 subjects left their jobs. Cox's proportional hazards model was used for analysis, adjusting for gender and age. Results: Less provision of social support by supervisors, colleagues, family or friends was significantly associated with increased risk of turnover. Financial aids for off-the-job training was marginally significantly associated with reduced risk of turnover. Longer duration of working for frail elderly care was significantly associated with decreased risk of turnover. Habitual smoking was significantly associated with increased risk of turnover. Conclusions: Social support in the workplace may be important to reduce the risk of turnover in care workers at GHs. Further prospective studies are required in other areas in Japan.
\end{abstract}

(J Occup Health 2013; 55: 487-494)

Received Nov 25, 2012; Accepted Sept 18, 2013

Published online in J-STAGE Oct 26, 2013

Correspondence to: M. Suzumura, Department of Public Health, Sapporo Medical University School of Medicine, South 1, West 17, Cho-ku, Sapporo, Hokkaido 060-8556, Japan (e-mail: miwasuzu@sapmed.ac.jp)
Key words: Care worker, Group home, Prospective study, Social support, Turnover

A higher staff turnover rate of care workers in nursing facilities for the elderly was reported $(21.9 \%)$ in $2008^{1)}$ as compared with the rate for general workers in 2008 ${ }^{2)}$ in Japan (13.8\%). A high turnover rate for staffs caring for people with dementia was also revealed in the United Kingdom in private facilities $(38 \%)$ and NHS facilities $(16 \%)^{3)}$. Moreover, the 1-year turnover rates were reported to be $56.4,39.7$ and $35.8 \%$ for certified nurse aides, licensed practical nurses, and registered nurses, respectively, in the $\mathrm{USA}^{4}$. These higher turnover rates might be caused by relatively lower wages ${ }^{5)}$, increased job stress ${ }^{6}$, reduced job satisfaction ${ }^{7}$ and less provision of social support ${ }^{6}$. Lack of employee continuity may contribute to recurring increased staff training costs and decreased quality of care provided to care receivers ${ }^{6}$. The significance of understanding turnover in the aged care setting is especially important when considering an aging population such as in Japan, in which, 31.6 and $38.8 \%$ of the Japanese population will be older than 65 in 2030 and 2055, respectively ${ }^{8}$.

Group homes for elderly individuals with dementia, abbreviated as GHs in this article, have spread widely throughout Japan since the $1990 \mathrm{~s}^{9)}$, and now, GHs are considered a type of community service, not a type of institutional service, in the National Care Insurance System in Japan. Because one unit in a GH consists of 5 to 9 inhabitants, and the allowed maximum number of units in a $\mathrm{GH}$ is 2 , only a small number of care workers work in a unit in a GH. Accordingly, care workers at GHs experience carry problems such as increased stress or anxiety. Furthermore, the environment in a $\mathrm{GH}$ sometimes tends to be too close, 
causing problems between inhabitants and care workers. In contrast to the stressful work environment in the GH in Japan, according to te Boekhorst et al. ${ }^{10)}$, job satisfaction was higher and burnout was lower in professional caregivers at GHs than in traditional nursing homes in the Netherlands.

Few prospective studies ${ }^{3)}$ have been conducted to assess risk factors associated with staff turnover in care workers, to our knowledge. Consequently, we conducted a prospective study of care workers at GHs to assess factors associated with risk of their turnover.

\section{Subjects and Methods}

The Ethics Committee at Sapporo Medical University approved this study in 2009. In January, 2010, 51 out of 238 GHs (21.4\%) in Sapporo City responded to our request for participation in a survey. During February and March of 2010, 438 out of 700 care workers $(62.6 \%)$ returned, by post, a completed questionnaire of a baseline survey directly to the Department of Public Health, Sapporo Medical University School of Medicine. The questionnaire included such things as demographic characteristics, experience in care giving, duration of working as a care staff number, average number of days and nights working in a month, wage, social support ${ }^{11)}$ from supervisors, colleagues, family or friends, depressive status according to the Center of Epidemiological Studies-Depression Scale (CES-D) ${ }^{12)}$ and Ozeki's coping style for stress ${ }^{13)}$.

We tried to conduct follow-up surveys for turnover twice, in March of 2011 and March of 2012, for the 438 study subjects. If a subject quit a job, his or her exact date and reason for quitting were asked. We sent the questionnaires for the follow-up surveys to the study subjects at their home addresses by post. Thereafter, 395 subjects $(90.1 \%)$ returned, by post, the completed questionnaires for the follow-up surveys directly to the Department. Data for the 3 surveys were connected based on the subjects' personal information including their full name. Eventually, 91 subjects left their jobs during the 2-year period.

The number of observational days was calculated as the date of turnover minus the date of the baseline survey for workers that left their jobs or as the date of the last follow-up survey minus the date of the baseline survey for workers continuing in a job. The turnover rate per person-year (\%) was calculated as the number of turnovers multiplied by both of 365.25 and 100 divided by the number of observational days. Cox's proportional hazards model ${ }^{14)}$ was used to find the association of potential factors with risk of turnover, adjusting for age and sex. SPSS 16.0 (Japanese version) was used for every analysis. The significance level was set at the $5 \%$ level.

\section{Results}

Table 1 shows hazard ratios (HRs) and their 95\%

Table 1. Age- and sex-adjusted hazard ratio (HR) and its $95 \%$ confidence interval (95\% CI) for turnover in workers at group homes for elderly individuals with dementia according to basic characteristics

\begin{tabular}{lcccccccc}
\hline Variables & Contents & $\begin{array}{c}\text { Number } \\
\text { of } \\
\text { subjects }\end{array}$ & $\begin{array}{c}\text { Observational } \\
\text { days }\end{array}$ & $\begin{array}{c}\text { Number of } \\
\text { turnover } \\
\text { subjects }\end{array}$ & $\begin{array}{c}\text { Turnover } \\
\text { rate per } \\
\text { person- } \\
\text { year }(\%)\end{array}$ & HR & 95\%CI & $p$ value \\
\hline Sex & Male & 57 & 31,467 & 17 & 19.7 & 1.00 & & \\
& Female & 338 & 196,410 & 74 & 13.8 & 0.78 & $0.46-1.34$ & 0.367 \\
& Total & 395 & 227,877 & 91 & 14.6 & & & \\
\hline Age & $20-29$ & 71 & 39,190 & 21 & 19.6 & 1.00 & & 0.395 \\
& $30-39$ & 82 & 46,298 & 19 & 15.0 & 0.76 & $0.41-1.42$ & 0.577 \\
& $40-49$ & 104 & 60,167 & 26 & 15.8 & 0.85 & $0.48-1.51$ & 0.309 \\
& $50-59$ & 97 & 57,760 & 17 & 10.8 & 0.58 & $0.31-1.11$ & 0.101 \\
& $60 \leq$ & 41 & 24,462 & 8 & 11.9 & 0.65 & $0.29-1.48$ & 0.309 \\
& Total & 395 & 227,877 & 91 & 14.6 & $p$ for trend=0.075 & \\
\hline Having spouse & Yes & 181 & 105,324 & 39 & 13.5 & 1.00 & & 0.748 \\
& No & 214 & 122,553 & 52 & 15.5 & 0.93 & $0.69-1.69$ & \\
\hline Total & 395 & 227,877 & 91 & 14.6 & & & \\
\hline Experience of & Yes & 123 & 72,694 & 22 & 11.0 & 1.00 & & 0.329 \\
fare for a fail & No & 272 & 155,183 & 69 & 16.2 & 1.29 & $0.78-2.13$ & \\
\hline
\end{tabular}


confidence intervals (95\% CIs) for turnover in the study subjects according to basic characteristics. As shown in Table 1, the turnover rate for all study subjects was $14.6 \%$ per person-year, and that of the female subjects $(13.8 \%$ per person-year) was lower than that of the male subjects $(19.7 \%$ per personyear), although the difference was not significant. Furthermore, older subjects had a lower risk of turnover than younger subjects, although the difference was also not significant. Analyses adjusted for age and sex revealed that, having a spouse was not associated with risk of turnover and that experience caring for a frail elderly family member was also not associated with risk of turnover.

Table 2 shows age- and sex-adjusted HRs and their $95 \%$ CIs for turnover in the study subjects according to working status. Risk of turnover was slightly higher in the subjects with a duration of working in frail elderly care of between 3 and 5 years than in those with a duration shorter than 3 years. However, risk of turnover was significantly lower in the subjects with a duration of working in frail elder care of 10 years or more ( $p$ for trend=0.029).

Wage was not associated with the risk of turnover. Moreover, since wage expectation was thought to be different between full-time workers and parttime workers, full-time workers and part-time workers were separately analyzed in terms of the association between wage and the risk of turnover. The results showed that wage was not associated with the risk of turnover either in full-time workers or part-time workers (data not shown). None of the subjects left their job because they had reached the end of their contract.

Other variables such as being proud of one's job, duration of working at present $\mathrm{GH}$, job status, average working days per month, average working nights per month, or being concerned about persons in the group home when not at work were not associated with risk of turnover.

Table 3 shows age- and sex-adjusted HRs and their 95\% CIs for turnover in the study subjects according to support from others. Less provision of support by a supervisor when consulted by a subject was significantly associated with an increased risk of turnover ( $p$ for trend $<0.001$ ). Similarly, less provision of support by colleagues when consulted by a subject was significantly associated with an increased risk of turnover ( $p$ for trend, $p=0.006$ ). Furthermore, less provision of support by family or friends when consulted by a subject was also significantly associated with an increased risk of turnover ( $p$ for trend, $p=0.010$ ).

Table 4 shows age- and sex-adjusted HRs and their 95\% CIs for turnover in the study subjects according to off-the-job training for care working. The results showed that financial aid for off-the-job training was marginally significantly associated with reduced risk of turnover $(\mathrm{HR}=0.64,95 \% \mathrm{CI} 0.40,1.01, p=0.05)$. However, presence of primary or midcourse off-thejob training in GHs was not associated with risk of turnover.

Table 5 shows age- and sex-adjusted HRs and their 95\% CIs for turnover in the study according to the CES-D score and Ozeki's coping style. The results showed that the CES-D score, problem-focused coping, emotional-focused coping and avoidance coping were not associated with risk of turnover.

Table 6 shows age- and sex-adjusted HRs and their 95\%CIs for turnover in the study subjects according to lifestyle habits. Habitual smoking was significantly associated with increased risk of turnover ( $p$ for trend, $p=0.006$ ). However, intention to continue present job, satisfaction of sleeping, usual effect of drinking and leisure time activities were not associated with risk of turnover.

\section{Discussion}

We found that less provision of support by a supervisor, colleagues, family or friends when consulted was strongly associated with risk of turnover in care workers in GHs, and these are the first findings obtained from a longitudinal study in Japan to our knowledge. Brannon et al. ${ }^{15)}$ showed that a care worker's assessment of the quality of supervision they received was inversely associated with the odds ratio for intent to quit a job. They ${ }^{15)}$ suggested that understanding of the caregiving role by a supervisor and colleague encouraged care workers in their respective jobs and their intention to retain their job. Karantzas et $a .^{6}{ }^{6}$ also suggested that supervisor support demonstrated numerous indirect inverse associations with job quitting intentions. Onodera et al. ${ }^{16)}$ showed that factor analysis of stressors in care workers for the elderly revealed four large factor structures including conflict with supervisor and conflict with colleagues. So et al. ${ }^{17)}$ also indicated with multiple linear regression analysis that competence and growth of care workers in special nursing homes was significantly positively associated with support from a supervisor or colleague. These findings might suggest that personal relationships with a supervisor or colleagues strongly affect risk of turnover in care workers. Anderson et $a l{ }^{18)}$ also explained that adequate staffing and longer nursing tenure of the nursing director were important predictors of reduced turnover risk.

Although we anticipated that there would be a positive relationship between stressful work environments and the turnover rate, we could not detect this relationship. Karantzas et al. ${ }^{6}$ ) showed that stressors directly influenced intentions to quit work based on 
Table 2. Age- and sex-adjusted hazard ratio (HR) and its $95 \%$ confidence interval (95\%CI) for turnover in workers at group homes for elderly individuals with dementia according to working status

\begin{tabular}{|c|c|c|c|c|c|c|c|c|}
\hline Variables & Contents & $\begin{array}{l}\text { Number of } \\
\text { subjects }\end{array}$ & $\begin{array}{c}\text { Observational } \\
\text { days }\end{array}$ & $\begin{array}{l}\text { Number of } \\
\text { turnover } \\
\text { subjects }\end{array}$ & $\begin{array}{c}\text { Turnover rate } \\
\text { per person- } \\
\text { year }(\%)\end{array}$ & HR & $95 \% \mathrm{CI}$ & $p$ value \\
\hline \multirow{5}{*}{$\begin{array}{l}\text { Total duration of } \\
\text { working in frail } \\
\text { elderly care }\end{array}$} & $<3$ years & 92 & 52,079 & 23 & 16.1 & 1.00 & & \\
\hline & $3-5$ years & 101 & 53,517 & 31 & 21.1 & 1.47 & $0.83-2.60$ & 0.187 \\
\hline & $6-9$ years & 116 & 68,927 & 27 & 14.3 & 1.06 & $0.59-1.92$ & 0.846 \\
\hline & $\geq 10$ years & 86 & 53,354 & 10 & 6.8 & 0.56 & $0.25-1.22$ & 0.141 \\
\hline & Total & 395 & 227,877 & 91 & 14.6 & \multicolumn{3}{|c|}{$p$ for trend $=0.029$} \\
\hline \multirow{5}{*}{$\begin{array}{l}\text { Duration of } \\
\text { working at present } \\
\text { group home }\end{array}$} & $<1$ year & 59 & 31,917 & 14 & 16.0 & 1.00 & & \\
\hline & $1-3$ years & 177 & 101,020 & 42 & 15.2 & 0.97 & $0.53-1.79$ & 0.931 \\
\hline & $4-7$ years & 142 & 83,472 & 34 & 14.9 & 0.95 & $0.51-1.77$ & 0.870 \\
\hline & $\geq 8$ years & 17 & 11,468 & 1 & 3.20 & 0.23 & $0.03-1.75$ & 0.155 \\
\hline & Total & 395 & 227,877 & 91 & 14.6 & \multicolumn{3}{|c|}{$p$ for trend $=0.510$} \\
\hline \multirow[t]{6}{*}{ Job status } & Full-time, regular work & 280 & 160,934 & 68 & 15.4 & \multicolumn{3}{|l|}{1.00} \\
\hline & Full-time, contractual work & 67 & 39,096 & 14 & 13.1 & 1.04 & $0.57-1.90$ & 0.903 \\
\hline & Part-time, regular work & 33 & 20,343 & 3 & 5.4 & 0.42 & $0.13-1.34$ & 0.141 \\
\hline & Part-tme, contractual work & 5 & 2,274 & 3 & 48.2 & 2.94 & $0.91-9.54$ & 0.073 \\
\hline & Others & 9 & 4,529 & 3 & 20.9 & 1.98 & $0.61-6.39$ & 0.254 \\
\hline & Total & $394^{\#}$ & 227,176 & 91 & 14.6 & & & \\
\hline \multirow{4}{*}{$\begin{array}{l}\text { Average working } \\
\text { days per month }\end{array}$} & $<15$ days & 52 & 31,715 & 7 & 8.10 & \multicolumn{3}{|l|}{1.00} \\
\hline & 16-21 days & 138 & 77,714 & 36 & 16.9 & 1.78 & $0.78-4.05$ & 0.172 \\
\hline & $\geq 22$ days & 205 & 118,448 & 48 & 14.8 & 1.53 & $0.68-3.45$ & 0.303 \\
\hline & Total & 395 & 227,877 & 91 & 14.6 & \multicolumn{3}{|c|}{$p$ for trend $=0.241$} \\
\hline \multirow{5}{*}{$\begin{array}{l}\text { Average working } \\
\text { nights per month }\end{array}$} & None & 77 & 46,497 & 12 & 9.4 & \multicolumn{3}{|l|}{1.00} \\
\hline & $1-4$ times & 120 & 70,146 & 28 & 14.6 & 1.54 & $0.76-3.10$ & 0.230 \\
\hline & 5-9 times & 193 & 108,050 & 50 & 16.9 & 1.58 & $0.83-2.99$ & 0.163 \\
\hline & $\geq 10$ times & 5 & 3,184 & 1 & 11.5 & 1.08 & $0.14-8.36$ & 0.940 \\
\hline & Total & 395 & 227,877 & 91 & 14.6 & \multicolumn{3}{|c|}{$p$ for trend $=0.265$} \\
\hline \multirow[t]{6}{*}{ Wages per month } & $<100,000$ yen & 52 & 29,894 & 10 & 12.2 & \multicolumn{3}{|l|}{1.00} \\
\hline & $100,00-149,999$ yen & 163 & 92,374 & 40 & 15.8 & 1.12 & $0.55-2.28$ & 0.755 \\
\hline & $150,000-199,999$ yen & 138 & 79,389 & 34 & 15.6 & 0.98 & $0.47-2.06$ & 0.957 \\
\hline & $200,000-249,999$ yen & 29 & 17,446 & 6 & 12.6 & 0.80 & $0.28-2.28$ & 0.681 \\
\hline & $\geq 250,000$ yen & 11 & 7,516 & 1 & 4.9 & 0.35 & $0.04-2.78$ & 0.322 \\
\hline & Total & $393^{\#}$ & 226,619 & 91 & 14.7 & \multicolumn{3}{|c|}{$p$ for trend $=0.305$} \\
\hline \multirow{5}{*}{$\begin{array}{l}\text { Being concerned } \\
\text { for persons in the } \\
\text { group home when } \\
\text { not at work }\end{array}$} & Always & 91 & 50,444 & 25 & 18.1 & \multicolumn{3}{|l|}{1.00} \\
\hline & Sometimes & 248 & 148,482 & 46 & 11.3 & 0.57 & $0.35-0.94$ & 0.027 \\
\hline & Scarcely & 46 & 24,440 & 15 & 22.4 & 1.15 & $0.60-2.18$ & 0.677 \\
\hline & None & 10 & 4,511 & 5 & 40.5 & 2.13 & $0.81-5.60$ & 0.126 \\
\hline & Total & 395 & 227,877 & 91 & 14.6 & \multicolumn{3}{|c|}{$p$ for trend $=0.347$} \\
\hline \multirow{4}{*}{$\begin{array}{l}\text { Being proud of } \\
\text { one's job }\end{array}$} & Yes & 306 & 180,177 & 65 & 13.2 & \multicolumn{3}{|l|}{1.00} \\
\hline & Scarcely & 78 & 42,156 & 22 & 19.0 & 1.32 & $0.81-2.16$ & 0.269 \\
\hline & No & 11 & 5,544 & 4 & 26.3 & 2.00 & $0.73-5.49$ & 0.178 \\
\hline & Total & 395 & 227,877 & 91 & 14.6 & \multicolumn{3}{|c|}{$p$ for trend $=0.107$} \\
\hline
\end{tabular}

\#: The number is lower due to missing values. 
Table 3. Age- and sex-adjusted hazard ratio (HR) and its 95\% confidence interval (95\% CI) for turnover in workers at group homes for elderly individuals with dementia according to support by others when consulted

\begin{tabular}{lcccccccc}
\hline Variables & Contents & $\begin{array}{c}\text { Number } \\
\text { of } \\
\text { subjects }\end{array}$ & $\begin{array}{c}\text { Observational } \\
\text { days }\end{array}$ & $\begin{array}{c}\text { Number } \\
\text { of } \\
\text { turnover } \\
\text { subjects }\end{array}$ & $\begin{array}{c}\text { Turnover } \\
\text { rate per } \\
\text { person- } \\
\text { year }(\%)\end{array}$ & HR & 95\%CI & $p$ value \\
\hline Support by & Yes & 184 & 111,260 & 33 & 10.8 & 1.00 & & \\
supervisors & So-so & 133 & 76,670 & 30 & 14.3 & 1.30 & $0.79-2.13$ & 0.300 \\
when consulted & Little & 55 & 30,551 & 16 & 19.1 & 1.82 & $1.00-3.31$ & 0.049 \\
& No & 22 & 8,692 & 12 & 50.4 & 4.89 & $2.51-9.52$ & $<0.001$ \\
& Total & $394^{\#}$ & 227,173 & 91 & 14.6 & $p$ for trend<0.001 & \\
\hline Support by & Yes & 237 & 140,451 & 48 & 12.5 & 1.00 & & 0.297 \\
colleagues when & So-so & 139 & 78,607 & 35 & 16.3 & 1.26 & $0.81-1.96$ & 0.069 \\
consulted & Little & 11 & 5,270 & 4 & 27.7 & 2.62 & $0.93-7.38$ & 0.069 \\
& No & 7 & 2,845 & 4 & 51.3 & 4.18 & $1.50-11.69$ & 0.006 \\
& Total & $394^{\#}$ & 227,173 & 91 & 14.6 & $p$ for trend=0.006 & \\
\hline Support by & Yes & 242 & 143,321 & 47 & 12.0 & 1.00 & & \\
family or friends & So-so & 126 & 71,273 & 34 & 17.4 & 1.46 & $0.94-2.27$ & 0.097 \\
when consulted & Little & 21 & 10,442 & 8 & 28.0 & 2.33 & $1.10-4.96$ & 0.028 \\
& No & 6 & 2,841 & 2 & 25.7 & 2.24 & $0.54-9.23$ & 0.266 \\
& Total & 395 & 227,877 & 91 & 14.6 & $p$ for trend=0.010 & \\
\hline
\end{tabular}

\#: The number is lower due to missing values.

Table 4. Age- and sex-adjusted hazard ratio (HR) and its $95 \%$ confidence interval (95\% CI) for turnover in workers at group homes for elderly individuals with dementia according to off-the-job training for care work

\begin{tabular}{|c|c|c|c|c|c|c|c|c|}
\hline Variables & Contents & $\begin{array}{l}\text { Number } \\
\text { of } \\
\text { subjects }\end{array}$ & $\begin{array}{c}\text { Observational } \\
\text { days }\end{array}$ & $\begin{array}{l}\text { Number } \\
\text { of } \\
\text { turnover } \\
\text { subjects }\end{array}$ & $\begin{array}{c}\text { Turnover } \\
\text { rate per } \\
\text { person- } \\
\text { year }(\%)\end{array}$ & HR & $95 \% \mathrm{CI}$ & $p$ value \\
\hline \multirow{3}{*}{$\begin{array}{l}\text { Primary off-the-job } \\
\text { training for care } \\
\text { working }\end{array}$} & Present & 216 & 128,275 & 44 & 12.5 & 1.00 & & \\
\hline & Absent & 178 & 98,898 & 47 & 17.4 & 1.40 & $0.92-2.11$ & 0.113 \\
\hline & Total & $394^{\#}$ & 227,173 & $88^{\#}$ & 13.7 & & & \\
\hline \multirow{3}{*}{$\begin{array}{l}\text { Midcourse off-the- } \\
\text { job training for care } \\
\text { working }\end{array}$} & Present & 323 & 189,081 & 72 & 13.9 & 1.00 & & \\
\hline & Absent & 71 & 38,088 & 19 & 18.2 & 1.49 & $0.89-2.50$ & 0.130 \\
\hline & Total & $394^{\#}$ & 227,169 & 91 & 14.6 & & & \\
\hline \multirow{3}{*}{$\begin{array}{l}\text { Financial aid for off- } \\
\text { the-job training }\end{array}$} & No & 90 & 48,370 & 26 & 19.6 & 1.00 & & \\
\hline & Yes & 302 & 177,416 & 65 & 13.4 & 0.64 & $0.40-1.01$ & 0.055 \\
\hline & Total & $392^{\#}$ & 214,786 & 91 & 15.5 & & & \\
\hline
\end{tabular}

\#: The number is lower due to missing values.

their survey measuring four aspects of stress, including role ambiguity, role conflict, work overload, and work-family conflict. Therefore, it is necessary for us to use more refined variables or scales to identify stressful work environments in a future study.

Longer duration of working in frail elderly care was not associated with reduced risk of turnover in our study. So et al. ${ }^{17)}$ reported that length of time in care work was significantly related to preparation for problem solving. Another possible explanation of this finding may be related to the fact that workers with maladjustment to the work environment in the $\mathrm{GH}$ are apt to leave there at an earlier time.

Financial aid for off-the-job training was marginally significantly associated with reduced risk of turnover in our study. Financial support for off-the-job train- 
Table 5. Age- and sex-adjusted hazard ratio (HR) and its $95 \%$ confidence interval (95\% CI) for turnover in workers at group homes for elderly individuals with dementia according to CES-D score and Ozeki's coping style

\begin{tabular}{|c|c|c|c|c|c|c|c|c|}
\hline Variables & Contents & $\begin{array}{c}\text { Number } \\
\text { of } \\
\text { subjects }\end{array}$ & $\begin{array}{l}\text { Observational } \\
\text { days }\end{array}$ & $\begin{array}{l}\text { Number } \\
\text { of } \\
\text { turnover } \\
\text { subjects }\end{array}$ & $\begin{array}{l}\text { Turnover } \\
\text { rate per } \\
\text { person- } \\
\text { year }(\%)\end{array}$ & HR & $95 \%$ CI & $p$ value \\
\hline \multirow[t]{3}{*}{ CES-D score } & $16<$ & 358 & 207,417 & 81 & 14.3 & 1.00 & & \\
\hline & $16 \geq$ & 36 & 19,868 & 10 & 18.4 & 1.21 & $0.62-2.34$ & 0.581 \\
\hline & Total & $394^{\#}$ & 227,285 & 91 & 14.6 & & & \\
\hline \multirow{4}{*}{$\begin{array}{l}\text { Problem-focused } \\
\text { coping }\end{array}$} & $0-4$ & 87 & 49,182 & 21 & 15.6 & 1.00 & & \\
\hline & $5-7$ & 133 & 74,756 & 36 & 17.6 & 1.09 & $0.64-1.87$ & 0.749 \\
\hline & $8-15$ & 167 & 98,444 & 34 & 12.6 & 0.78 & $0.45-1.35$ & 0.379 \\
\hline & Total & $387^{\#}$ & 222,382 & 91 & 14.8 & & $p$ for trend $=0.101$ & \\
\hline \multirow{4}{*}{$\begin{array}{l}\text { Emotional-focused } \\
\text { coping }\end{array}$} & $0-3$ & 82 & 47,116 & 20 & 15.5 & 1.00 & & \\
\hline & $4-6$ & 185 & 107,028 & 45 & 15.3 & 1.04 & $0.61-1.76$ & 0.892 \\
\hline & $7-9$ & 121 & 68,911 & 26 & 13.8 & 0.97 & $0.54-1.74$ & 0.907 \\
\hline & Total & $388^{\#}$ & 223,055 & 91 & 14.9 & & $p$ for trend $=0.639$ & \\
\hline \multirow[t]{4}{*}{ Avoidance coping } & $0-6$ & 101 & 60,719 & 20 & 12.0 & 1.00 & & \\
\hline & $7-12$ & 224 & 127,134 & 57 & 16.4 & 1.43 & $0.86-2.38$ & 0.172 \\
\hline & $13-18$ & 62 & 34,529 & 14 & 14.8 & 1.39 & $0.70-2.77$ & 0.354 \\
\hline & Total & $387^{\#}$ & 222,382 & 91 & 14.9 & & $p$ for trend $=0.460$ & \\
\hline
\end{tabular}

\#: The number is lower due to missing values.

ing may help care workers to improve their ability to deal with care receivers, because Nitta et $a l .{ }^{19)}$ as well as Miura and Kato $^{20)}$ showed a significantly good effect of training in terms of care for the elderly with dementia. However, Banaszak-Holl and Hines ${ }^{21)}$ indicated that total hours of training were not related to turnover rate of nursing aides in nursing homes.

Wage was not associated with the risk of turnover either in full-time workers or part-time workers. Although we compared reasons for turnover between full-time workers and part-time workers, the proportions of reasons such as worsened relationship with inhabitants or co-workers, low wage, anxiety for future life and health problem, were not significantly different between the 2 groups. According to the result of the Danish Nurse Cohort Study by Friis et $a l .^{22)}$, nurses who had relatively low gross incomes showed an increased probability of early retirement. Hanaoka $^{5)}$ also reported that lower wages had a significant effect on increased risk of turnover, especially, during a year after employment.

We found that being proud of one's job was not associated with risk of turnover. Several previous reports indicated that job satisfaction was associated with lower risk of turnover ${ }^{6,23,24)}$. Ogiso et al. ${ }^{23)}$ reported that higher professional pride was related to lower risk of turnover. Karantzas et al. ${ }^{6}$ suggested that lower job satisfaction directly influenced intention to quit a job among care staff in the aged care sector. Castle et $a .^{24)}$ also indicated that high overall job satisfaction was associated with lower risk of turnover in nursing aides in nursing homes.

Smoking habits were significantly associated with risk of turnover in our study. Although we could not find any article indicating a relationship between smoking habits and turnover in care workers, it is thought that stress may be associated with both habitual smoking and staff turnover. However, relationships of smoking habits with the CES-D score or coping style were not statistically significant in our study (data were not shown). In addition, it is possible that workers with smoking habits would be subjects that might quit their job because of a smoking-related health problem.

The yearly turnover rate of our study subjects (14.6\%) was shown to be a little higher, but not by much, than that of general workers in Japan $(13.5 \%)^{2}$. Selection bias may exist in our study and might have resulted in the relatively lower turnover rate in $\mathrm{GH}$ workers, because only $21.4 \%$ of $\mathrm{GHs}$ and $62.6 \%$ of care workers at them participated in the study. Furthermore, because the work environment of care workers in Sapporo City may be different from other areas in Japan, our findings should not be generalized to the entirety of Japan. In particular, because the lowest legal wage in Sapporo City is lower than that 
Table 6. Age- and sex-adjusted hazard ratio (HR) and its $95 \%$ confidence interval (95\% CI) for turnover in workers at group homes for elderly individuals with dementia according to lifestyle habits

\begin{tabular}{|c|c|c|c|c|c|c|c|c|}
\hline Variables & Contents & $\begin{array}{c}\text { Number } \\
\text { of } \\
\text { subjects }\end{array}$ & $\begin{array}{c}\text { Observational } \\
\text { days }\end{array}$ & $\begin{array}{l}\text { Number } \\
\text { of } \\
\text { turnover } \\
\text { subjects }\end{array}$ & $\begin{array}{c}\text { Turnover } \\
\text { rate per } \\
\text { person- } \\
\text { year }(\%)\end{array}$ & HR & $95 \% \mathrm{CI}$ & $p$ value \\
\hline \multirow{5}{*}{$\begin{array}{l}\text { Intention to } \\
\text { continue } \\
\text { present job }\end{array}$} & Strongly want to continue & 128 & 74,773 & 29 & 14.2 & 1.00 & & \\
\hline & Slightly want to continue & 201 & 118,921 & 40 & 12.3 & 0.92 & $0.57-1.50$ & 0.748 \\
\hline & Slightly want to quit & 54 & 28,054 & 19 & 24.7 & 1.67 & $0.93-2.98$ & 0.087 \\
\hline & Strongly want to quit & 10 & 4,858 & 3 & 17.9 & 1.56 & $0.47-5.12$ & 0.466 \\
\hline & Total & $393^{\#}$ & 226,606 & 91 & 14.7 & \multicolumn{2}{|c|}{$p$ for trend $=0.542$} & \\
\hline \multirow{5}{*}{$\begin{array}{l}\text { Satisfaction } \\
\text { of sleeping }\end{array}$} & Very satisfied & 115 & 65,826 & 28 & 15.5 & 1.00 & & \\
\hline & Slightly satisfied & 159 & 91,629 & 37 & 14.7 & 0.89 & $0.54-1.46$ & 0.652 \\
\hline & Slightly unsatisfied & 93 & 54,691 & 19 & 12.7 & 0.77 & $0.43-1.39$ & 0.390 \\
\hline & Very unsatisfied & 28 & 15,731 & 7 & 16.2 & 1.06 & $0.46-2.44$ & 0.899 \\
\hline & Total & 395 & 227,877 & 91 & 14.6 & \multicolumn{2}{|c|}{$p$ for trend $=0.646$} & \\
\hline \multirow[t]{5}{*}{ Smoking } & Never & 171 & 102,352 & 30 & 10.7 & 1.00 & & \\
\hline & Quitting & 82 & 48,879 & 14 & 10.5 & 1.01 & $0.53-1.91$ & 0.989 \\
\hline & Sometimes & 21 & 10,501 & 8 & 27.8 & 2.39 & $1.09-5.25$ & 0.030 \\
\hline & Daily & 121 & 66,145 & 39 & 21.5 & 1.84 & $1.14-2.98$ & 0.013 \\
\hline & Total & 395 & 227,877 & 91 & 14.6 & \multicolumn{2}{|c|}{$p$ for trend $=0.006$} & \\
\hline \multirow{4}{*}{$\begin{array}{l}\text { Usual effect } \\
\text { of drinking }\end{array}$} & Little effect & 153 & 88,289 & 36 & 14.5 & 1.00 & & \\
\hline & Slightly drunk & 173 & 101,373 & 34 & 12.3 & 0.71 & $0.44-1.15$ & 0.167 \\
\hline & Somewhat drunk & 69 & 38,215 & 21 & 20.1 & 1.21 & $0.70-2.09$ & 0.498 \\
\hline & Total & 395 & 227,877 & 91 & 14.6 & \multicolumn{2}{|c|}{$p$ for trend $=0.665$} & \\
\hline \multirow{3}{*}{$\begin{array}{l}\text { Leisure time } \\
\text { activities }\end{array}$} & Yes & 166 & 96,538 & 36 & 13.6 & \multicolumn{2}{|l|}{1.00} & \multirow{3}{*}{0.438} \\
\hline & No & 229 & 131,339 & 53 & 14.7 & \multirow[t]{2}{*}{1.19} & \multirow[t]{2}{*}{$0.77-1.82$} & \\
\hline & Total & 395 & 227,877 & $89^{\#}$ & 14.3 & & & \\
\hline
\end{tabular}

\#: The number is lower due to missing values.

in other areas of Japan, it is possibly difficult to find a significant association between lower wages and an increased risk of turnover in Sapporo City compared with in other areas of Japan.

In conclusion, less provision of social support by supervisors, colleagues, family or friends was significantly associated with increased risk of turnover. Social support in the workplace may be important to reduce risk of turnover in care workers at GHs. Further prospective studies are required with a longer duration in other areas of Japan.

Acknowledgments: This study was supported with a grant from Hokkaido Kosyu Eisei Kyokai.

\section{References}

1) Kaigo Rodo Anzen Center. Current status of care workers: results from survey for care workers in the year 2008: (Japanese text). [Online].2008 [cited 2013 Apr 21]; Available from: URL: http://www. kaigo-center.or.jp/report/pdf/h20_roudou_genjyou.pdf

2) Owada T. Social and care worker issues in special nursing homes for the elderly. J Aomori Univ Health Welfare 2009; 10: 139-54 (in Japanese).

3) Margallo-Lana $M$, Reichelt $K$, Hayes $P$, et al. Longitudinal comparison of depression, coping, and turnover among NHS and private sector staff caring for people with dementia. Br Med J 2001; 31: 769-70.

4) Castle NG, Engberg J. Organizational characteristics associated with staff turnover in nursing homes. Gerontologist 2006; 46: 62-73.

5) Hanaoka C. Care staff turnover in long-term care services for older people: how does the effect of relative wages on turnover by tenure? Iryo Keizai Kenkyu 2011; 23: 39-57 (in Japanese).

6) Karantzas GC, Mellor D, McCabe MP, Davison TE, Beaton P, Mrkic D. Intentions to quit work among care staff working in the aged care sector. Gerontologist 2012; 52: 506-16.

7) Matsumoto K. A study on working environment and 
job satisfaction of professional caregivers and their turnover. Kumamoto Univ Igakubu Hokenkagaku Kiyo 2011; 7: 85-105 (in Japanese).

8) Ito $M$, Shiina $M$, Endo $H$, et al. Trend in National Health in 2012/2013. J Health Welfare Stat 2012; 59 (Suppl): 44 (in Japanese).

9) Furumura M. Difficulties faced by caregivers at group homes for elderly with dementia and related factors. Nihon Kosyu Eisei Zasshi 2011; 58: 583-94 (in Japanese).

10) te Boekhorst S, Willemse B, Depla MFIA, Eefsting JA, Pot AM. Working in group living homes for older people with dementia: the effects on job satisfaction and burnout and the role of job characteristics. Int Psychogeriat 2008; 20: 927-40.

11) Kobayashi K, Miyake H, Okano G, Mori M. Association of cognitive style and satisfaction with depressive symptoms in workers in Hokkaido, Japan. Sapporo Medical J 2006; 75: 37-50.

12) Shima $S$, Shikano T, Kitamura $T$, Asai M. New selfrating scales for depression. Clin Psychiat 1985; 27 : 717-23 (in Japanese).

13) Ozeki Y, Haraguchi M, Tsuda A. Analysis of covariance structures of psychological stress process for college students. Jpn J Health Psychol 1994; 7: 20-36 (in Japanese).

14) Cox RD. Regression models and life tables (with discussion). J Roy Stat Soc 1972; B34: 187-220.

15) Brannon D, Barry T, Kemper P, Schreiner A, Vasey J. Job perceptions and intent to leave among direct care workers: evidence from the better jobs better care demonstrations. Gerontologist 2007; 47: 820-9.

16) Onodera A, Azechi R, Shimura Y. Relationship between stressors and burnout in care staff for the elderly. Ronen Shakai Kagaku 2007; 28: 464-75 (in Japanese).
17) So JY, Okada S, Shirasawa M. Factors related to perceived job competence of care workers in nursing homes. Study of Social Welfare 2007; 47: 124-35 (in Japanese).

18) Anderson RA, Corazzini KN, McDaniel Jr RR. Complexity science and the dynamics of climate and communication: reducing nursing home turnover. Gerontologist 2004; 44: 378-88.

19) Nitta S, Uemura N, Mochizuki N. Relationship between basic knowledge about dealing with behavioral and psychological symptoms of dementia (BPSD) and professional careers in staff members at special care facilities for dementia (Group Home). Yamanashi Nurs J 2008; 7: 27-32 (in Japanese).

20) Miura K, Kato S. Relationship between understanding behavioral and psychological symptoms of dementia (BPSD) and training caregivers. Efficacy of internal training and length of service. Nihon Ninchisyo Care Gakkaishi 2009; 8: 51-9 (in Japanese).

21) Banaszak-Holl J, Hines MA. Factors associated with nursing home staff turnover. Gerontologist 1996; 36: 512-7.

22) Friis K, Ekholm O, Hundrup YA, Obel EB, Grønbæk M. Influence of health, lifestyle, working conditions, and sociodemography on early retirement among nurses. The Danish Nurse Cohort Study. Scand J Publ Health 2007; 35: 23-30.

23) Ogiso K, Abe T, Andou S, Hirasawa Y. Factors related to overall job satisfaction, resignation, and change of workplace. Shakai Fukushi Gaku 2010; 51: 103-18 (in Japanese).

24) Castle NG, Engberg J, Anderson R, Men A. Job satisfaction of nurse aides in nursing homes: intent to leave and turnover. Gerontologist 2007; 47: 193-204. 